\title{
A komplementer és alternatív medicina felé orientálódó terápiaválasztást meghatározó tényezők
}

\author{
Zörgő Szilvia - Purebl György dr. - Zana Ágnes dr. \\ Semmelweis Egyetem, Általános Orvostudományi Kar, Magatartástudományi Intézet, Budapest
}

\begin{abstract}
Bevezetés: A komplementer és alternatív medicina egészségügyi piacon történő térnyerése megkérdőjelezhetetlen, fontos kérdés tehát, hogy a betegek miért választják az ilyen gyógymódokat, ezzel gyakran megszakítva a nyugati medicina keretében zajló terápiás folyamatot. Célkitüzés: A szerzók célja azoknak a tényezőknek a feltérképezése és elemzése, amelyek miatt a betegek a különböző alternatív medicinák szolgáltatásait igénybe veszik. Módszer: A kvalitatív kutatás alapja egy hagyományos kínai orvoslást nyújtó rendelőben végzett orvosi antropológiai terepmunka: résztvevő megfigyelés ( 355 óra), strukturálatlan interjúk betegekkel $(\mathrm{n}=93)$ és mélyinterjúk $(\mathrm{n}=14)$. Eredmények: Az alternatív medicinát alkalmazó betegek gyakran nem kapnak a nyugati orvoslástól diagnózist, magyarázatot vagy gyógymódot betegségükre, illetve ezek valamelyike a beteg számára nem volt elfogadható. Máskor a betegek azért választják az alternatív medicinát, mert filozófiai kongruenciát mutat olyan világ-, ember- és betegségképbeli képzetekkel, amik eleve magyarázó modelljük részét képezik. Köpetkeztetések: Egy adott terápia mindig egy kulturális rendszer része, valamint egy specifikus pszichoszociális kontextusba ágyazott jelenség, így a terápiaválasztás is csak ennek fényében értelmezhető. Orv. Hetil., 2016, 157(15), 584-592.
\end{abstract}

Kulcsszavak: terápiaválasztás, nyugati orvoslás, komplementer és alternatív medicina, orvosi antropológia, globalizáció

\section{Factors determining selection of treatment options oriented towards complementary and alternative medicine}

Introduction: Complementary and alternative medicine have undoubtedly been gaining ground on the healthcare market, thus the vital question arises why patients choose these treatments, oftentimes at the cost of discontinuing the Western medical therapy. Aim: The aim of the authors was to investigate and scrutinize factors leading to the utilization of various alternative medical services. Method: The basis of this qualitative research was medical anthropological fieldwork conducted at a clinic of Traditional Chinese Medicine including participant observation (355 hours), unstructured interviews with patients $(n=93)$ and in-depth interviews $(n=14)$. Results: Patients of alternative medical systems often do not receive a diagnosis, explanation or cure for their illness from Western medicine, or they do not agree with what they are offered. In other instances, patients choose alternative medicine because it exhibits a philosophical congruence with their already existing explanatory model, that is, previous concepts of world, man or illness. Conclusions: A particular therapy is always part of a cultural system and it is embedded in a specific psycho-social context, hence choice of therapy must be interpreted in accordance with this perspective.

Keywords: therapy choice, Western medicine, complementary and alternative medicine, medical anthropology, globalization

Zörgö, Sz., Purebl, Gy., Zana, Á. [Factors determining selection of treatment options oriented towards complementary and alternative medicine]. Orv. Hetil., 2016, 157(15), 584-592.

(Beérkezett: 2016. január 22.; elfogadva: 2016. február 18.)

\section{Rövidítések}

HKO = hagyományos kínai orvoslás; IPA = interpretatív fenomenológiai analízis; KAM = komplementer és alternatív medicina; TACE $=$ transarterialis katéteres chemoembolisatio
A komplementer és alternatív medicina (KAM) igénybevételéről számtalan statisztika áll rendelkezésre, amelyek rendkívül összetett, de nem egységes szempontok alap- 
ján mutatják be a KAM használatát. Egy 2002 -es felmérés szerint az Amerikai Egyesült Államok felnőtt lakosságának 36-42\%-a vesz igénybe KAM-szolgáltatást [1, 2], későbbi statisztikák $72 \%$-ról számolnak be $[3,4]$. Európában 2013-ban a lakosság 56\%-a preferálta a KAM-ot [5]. Hazai hasonló országos reprezentációjú vizsgálat viszont utoljára 1999-ben készült, ekkor a felnőtt lakosság $23,1 \%$-a élt ezzel a lehetőséggel, legalább egyszer [6].

A statisztikák meghatározó tényezői többek közt: a vizsgálat módszere; a vizsgált csoport/minta összetétele; a vizsgálat helyszíne és kulturális értékei (világ-, ember-, betegségkép, hagyományos gyógyászati rendszer); a beteg konkrét betegsége és lefolyása, annak kulturális és személyes megítélése; a betegség tünetei stb. Mivel a statisztikák ilyen sok tényező függvényében születnek meg, sokszínú eredményeket tárnak elénk, és ezért nehezen összehasonlíthatóak. Például Ghánában a rákos betegek 73,5\%-a vesz igénybe KAM-kezelést [7], de Afrikában a lakosság 70\%-a nem tudja megfizetni a nyugati kezelést, és sokszor már túl későn diagnosztizálják a daganatos megbetegedést ahhoz, hogy egyáltalán szóba kerüljön a nyugati gyógymód. A daganatos betegek körében végzett kutatások Európában szintén magas arányát találták a KAM-nak $(83 \%)[2,8]$, de ezt is befolyásolja a betegség prognózisa és az alkalmazható nyugati terápia elérhetősége. Amerikában 212 megkérdezett rákbeteg 34\%-a vett igénybe KAM-ot [2], de a kutatók csak a biológiai alapú KAM-ot (természetes anyagokból készült termékek) vizsgálták az adott közösségben (1. fázisú rákbeteg), ami erősen korlátozza a vizsgálat tárgyát. Svédországban ez a szám 53\% volt [8], a vizsgálat azonban kizárólag a tüdőrákos betegekre terjedt ki. Malajziában HIV/AIDS betegek körében 78,2\% volt a KAM-igénybevétel [9], de a minta mindössze egy adott kórházat látogatókra korlátozódott.

Szociodemográfiai szempontból is csak relatív képet kaphatunk a KAM-felhasználók jellemzőiroól. Számos tanulmány a következő, KAM-használattal kapcsolatos szociodemográfiai faktorokat emeli ki: nő, középkorú, magas iskolai végzettségú, magas jövedelmú, több diagnózissal bíró, hosszan tartó megbetegedéssel küzdő beteg, akinek terápiaválasztásában nagyban közrejátszik az egészségügyi biztosítása $[4,9]$. Mindemellett fontos a KAM-szolgáltatás elérhetősége és láthatósága, a beteg lakhelye, vallása, etnikuma, szubkultúrája, életmódja, családi szocializációja, hivatása, szexuális orientációja és betegségének állapota [1]. Összefoglalóan: az adatok sokszínúek és nehezen összevethetóek, az azonban mindenképpen megállapítható, hogy az Amerikai Egyesült Államokban és Európában egyre többen veszik igénybe az alternatív medicinák által nyújtott terápiákat.

A KAM egyre növekvő térhódítása az egészségügyi piacon egyfelól jelzi, hogy jelentős igény van különböző fajta gyógyító rendszerekre, másfelől e szolgáltatások elterjedése számottevő hatással van a lakosság egészséggelbetegséggel kapcsolatos koncepcióira és döntéseire. Bár a nyugati orvoslás tekintélye továbbra is megkérdőjelezhetetlen, piaci helyzetének komplexitása megmutatkozik a betegek terápiaválasztással kapcsolatos folyamataiban és konkrét döntéseiben. Hiszen az egyén döntései a társadalmi struktúra viszonylatában, a benne jelen lévő és azt generáló erők hatására születnek [1].

$\mathrm{Az}$ alábbi írás igyekszik bemutatni azokat a tényezőket, amelyek végül a beteget a KAM-szolgáltatások igénybevételéhez vezetik. Az itt közölt tényezők önmagukban nem elegendők a terápiaválasztás értelmezéséhez, hiszen meghatározott kulturális kontextusba ágyazottak, ezért e téma kapcsán elengedhetetlen az adott kontextus rövid ismertetése.

\section{Globalizációs hatások}

A globalizációs hatások három fó területen nyilvánulnak meg a terápiaválasztás folyamatában: piaci verseny, információáramlás és kulturális „kreolizáció” [10]. Abban, hogy melyik alternatív gyógyászati szolgáltatás mennyire elérhető a beteg számára, nagy szerepe van a mindenkori (kül)politikai megfontolásoknak és az így kialakuló egészségügyi piaci helyzetnek. Már maga a törvényi szabályozás és képzési, praktizálási lehetôségek jelzik egy bizonyos medicina társadalmi és tudományos elfogadottságát (például: „csak orvos által végezhető tevékenység", részletesebben lásd: [11]), valamint befolyásolja is azt, hogy hányan, milyen feltételekkel múvelik és veszik igénybe. Továbbmenve az, hogy egy átlagos beteg milyen könnyen fér hozzá egy adott medicina terápiájához, erôsen függ a terápia politikai értékétől. Nemzetközi kapcsolatok szempontjából egy adott medicina is értékesíthető kulturális termékként jelenhet meg és piaci, szakmai és kulturális együttmúködés eszközévé válhat, mint például a hagyományos kínai orvoslás (HKO). A jelenleg Budapestre tervezett közép- és kelet-európai HKO-központ kiváló illusztrációja egy ilyen gazdaságpolitikai gravitációs pontnak, amely oktatási, kutatási és gyógyítási szempontból nemcsak a HKO presztízsét növeli, hanem egyúttal hozzáférhetőségét is.

A piaci verseny nemcsak a szolgáltatások igénybevételére terjed ki, hanem a magyarázó modellekre is, beleértve a világ-, ember- és betegségképet. Molnár szerint: „Az egymást kölcsönösen bíráló és kizáró világnézetek tengerében ... nincsenek meg a korábbi biztos pontok. Minden állításnak létrejött a tagadása, a bírálata, és az egyénnek magának kell megtalálnia és megalkotnia világképét. ... Ma már nem arról van szó, hogy az egyén szabadon választhat a versengő világnézetek között, hanem arról, hogy választania kell" [12]. Az ellentmondások, paradoxonok és bizonytalanságok [10] a betegséggel kapcsolatos jelenségekre is levetülnek. „A test - írja Van Wolputte - a hatalom és ellenszegülés találkozási pontjává vált." A versengés nemcsak az anyagi haszonról szól, hanem a szakmai presztízsról és a medicinához társított értékek többségi társadalom által való elfogadásáról is. Így kulcsfontosságú az, hogy miként jelenik meg egy bi- 
zonyos medicina a társadalom számára, azaz milyen imázst formál magának és hogyan ítéltetik meg. A szakmai tekintély kérdése központi: a sikeres medicina nemcsak szolgáltatásait tudja érvényesíteni, népszerüsíteni, hanem világképének dominanciáját a többségi társadalom értékrendszerében is képes biztosítani, ezáltal meghatározva a többi medicina kulturális rendszerének relatív helyzetét.

A soha nem látott mennyiségú információtermelés a globalizáció társjelensége, és ahogy a különböző kulturális elemek, rendszerek „átutazzák” a világot, hatnak a helyi (lokális) kultúrára, így a világképre, az emberképre és a gyógyászati elképzelésekre is. Az új kulturális jelenségek beépülnek, integrálódnak a helyi kultúrába, illetve a jelenség maga átalakul a lokális normarendszer értelmezése szerint (vö. „glokalitás” fogalma, lásd: [13]). Az információ elburjánzása nemcsak bizonyos információszúrési kompetenciákat követel meg (különbséget tenni „értékes” és „érdektelen” információ között), hanem felmerül az információ termelésének kérdésköre is. Mára az információ előállítása is policentrikus és diffúz [14], amit az egy adott témában megjelenő tartalmak tükröznek is: ellentmondásos „tényekkel”, véleményekkel találkozunk.

Egészségügyi kérdésekben is verseny tapasztalható a különböző információtermelési források, intézmények, gyógyászati rendszerek között, így a beteg már a terápia választás előtt, a tüneteiről, betegségéről való tájékozódás fázisában, voltaképpen értékei és elképzelései szerint rangsorolja a lehetséges információforrásokat, ezáltal megszürve a kérdéseire és lehetőségeire vonatkozó információ tartalmát is. Komplex kölcsönhatási folyamat áll fenn az egyén meglévő, előzetes elképzelései alapján kialakított „információszűrője” és a számára feltárulkozó információhalmaz között, amely nem feltétlenül annyira plasztikus, mint gondolnánk. Az internet például szinte határtalan információhalmazt tár elénk, de az, ami alapján navigálunk benne (és ezáltal szelektálunk), már valamilyen mértékben előzetes képzeteink, asszociációnk függvénye, valamint annak, hogy számunkra melyek a "hiteles” információforrások.

Az információszưrés kapcsán felmerül az is, hogy a „megbízható” és a „hamis” információ hogyan különböztethető meg, amelyhez szükségesek az autentikusság, a hitelesség, valamint a megbízhatóság forrását jelentő orientációs pontok. Ahogy Molnár írja, a kulturális intézmények tekintélyvesztéséből kifolyólag a tájékozódási pontok nem egyértelmúek, az „igazság” és a „tény” szubjektív bírálat alá esik: „Nem az intézmény, hanem az egyén lett a döntés alapja, és a hagyomány helyett egyre inkább a tapasztalat ... vált az autentikusság forrásává" [12]. A személyes tapasztalat a terápiaválasztásban is nagy szerepet játszik, hiszen a kipróbált terápia megítélése egyfelől meghatározza jövőbeni igénybevételét, másfelől alapját képezi annak az egészségügyi témákkal kapcsolatos, betegek közti információáramlásnak, amely a személyes tapasztalat és preferenciák átadásáról szól. A KAM világában ez az információáramlás a legfontosabb, a bete- get leginkább befolyásoló terápiaválasztási tényező és a személyes tapasztalattal rendelkező „másik” jelenti az autentikusság, megbízhatóság forrását. A beteg számára a „másik” lehet akár laikus is, akinek ugyanolyan betegsége van vagy volt, mint neki, és lehet természetgyógyász, akinek az adott betegség kezelésében szakemberként van tapasztalata. A kulturális intézményekbe vetett bizalom elvesztésének az az eredménye, hogy az individuum a bizalmat sorstársaiban találja meg, a „hiteles” információ kizárólag első kézből kapható. A hitelesnek ítélt források hierarchiájában első helyen a személyes tapasztalattal rendelkező „másik” áll, második helyen pedig azok a források, amiket a „másik” javasol (például: egy honlap, egy könyv, egy intézmény, egy szakember stb.).

A globális piac és információáramlás mellett a globalizáció egy fontos következménye a kulturális „kreolizáció”, azaz a különböző kulturális rendszerek, tradíciók integrálása, amely identitásépítő mechanizmusként is azonosítható [10]. A fragmentált és ellentmondásos társadalmi jelenségek miatt az identitás, az Én (szelf) is fragmentált: megosztott, hibrid, gyakran inkoherens, következetlen, amely vitathatóan a késő kapitalizmus, a posztmodern és a posztkoloniális jelenségek következménye [10]. Az adott társadalmi miliőben túlélési stratégiát jelenthet a bizonyos értékeken, elképzeléseken alapuló kulturális „szemezgetés”, amely jellemző a Ray által leírt, úgynevezett „kulturális kreatívokra”, akik, felmérése szerint, az amerikai felnőtt lakosság 24\%-át teszik ki [1]. Közös értékeik közé tartoznak az ökológiai fenntarthatóságra való törekvés, az egzotikus és idegen preferálása, a társadalmi optimizmus, és a spiritualitás, amely a test-lélek-elme egységében fogható meg és e világszemléletben központi szereppel bír [1]. A kulturális kreatívok világ-, ember- és betegségképe, valamint a KAM között kölcsönhatás van: a KAM e nehezen meghatározható világnézetnek egyben egyik „mozgatórugója” és „terméke”.

Tehát, egyfelől, a globális piac és információáramlás lehetővé teszik a különböző alternatív medicinák szolgáltatásainak elterjedését, másfelől a kulturális „kreolizáció" jelzi a piaci helyzet leképeződését az egyénben: versengő világnézetek és praxisok interakciója, szelekciója és integrálása. Az információforrások közti orientációban a személyes tapasztalat, illetve az ezzel rendelkező „másik” válik kulcsfontosságúvá, a „hitelesség” és „igazság” egyre inkább szubjektív. Ezek a folyamatok tükrözik és tovább serkentik a normarendszer változását, amely nemcsak az egyén világ-, ember- és betegségképét érintik, hanem a gyógyítóval és gyógyászati rendszerrel szembeni elvárásait is. A terápiaválasztással kapcsolatban a kulturális „kreolizáció” két nagyon fontos hatásterülete az egészségdefiníció (lásd: biopszichoszociális modell térnyerése), és az etiológia (mit tekintünk egy betegség „okának” és mit „tünetének”).

A terápiaválasztás tényezői tehát e globális miliő lokális beágyazottságában értelmezhetők és egyaránt reakciók a nyugati orvoslás hazai helyzetére, a hazai ellátás jellegze- 
tességeire, valamint reakciók az alternatív medicinák kulturális rendszerekként történő elterjedésére. Azért szükséges kulturális rendszerként tekinteni ezekre a medicinákra (beleértve a nyugati medicinát is), mert sosem csak egy adott terápiáról van szó, mindig egy szociokulturális kontextusba ágyazott jelenségről. Így a döntési tényezőket érdemes kontextusaik alapján rendszerezni, amelyre például Lövgren is kísérletet tesz, aki „push” (a pácienst a nyugati medicinától eltávolító, eltoló tényezők) és „pull” (a KAM irányába húzó, vonzódást előidéző) faktorokra bontja. Jelen írás nem egy dichotóm kategóriarendszert állít fel, hanem a betegekben fellépő különböző igények mentén igyekszik rendszerezni a jelenségeket.

Stratton szerint az alternatív medicina voltaképpen a nyugati orvoslás által teremtett piaci réseket tölti be, ott erős, ahol a nyugati terápiák és/vagy emberkép hiányokat szenved, illetve olyan kérdésekben, amelyeknek fontosságát egyszerüen elveti (vö.: [15]). Ez, Stratton kifejtésében, leginkább a fájdalommal és a szenvedéssel való megküzdés, a tünet jelentéssel való felruházásában nyilvánul meg. Ellenben, mint később látható, ez a terület nem meríti ki a fellépő igények skáláját és nem is redukálható egy egyszerü „hiányra”, amit a páciens a nyugati orvoslás modelljében felfedezni vél.

\section{Módszer}

Az alábbiakban összefoglalt ismeretanyag kulturális antropológiai terepmunkán alapszik (résztvevő megfigyelés és interjúzás), amely 2014 szeptemberében kezdődött az egyik hagyományos kínai orvoslással foglalkozó budapesti rendelőben. A kutatás a cikk megírásának idejében körülbelül 150 pácienst vont be valamilyen formában: betegfelvétel/konzultáció megfigyelése (53 fö); spontán, strukturálatlan interjúk kezelt betegekkel (93 fó); mélyinterjúk kezelt betegekkel ( 8 fó) és kezelőkkel (6 fö). A félig strukturált mélyinterjúk elemzése interpretatív fenomenológiai analízissel (IPA) történt. A résztvevő megfigyelés során terepnapló készül, az információ minden sora kódolásra kerül az Atlas.ti program segítségével. A kezdeti nyitott kódok a narratívák folyamatos újraolvasásával, induktív analízis és axiális kódolás révén dinamikus kategóriákba kerülnek.

Az alábbi kategóriarendszer szerint ismertetett példák a terepmunka során kerültek rögzítésre; a betegektől származó idézetek a következőkben dőlt betúkkel szerepelnek. A KAM felé orientáló terápiaválasztási tényezők a betegekben kialakult igények alapján kerülnek ismertetésre. Ezek mindegyike komplex témakör és jóval részletesebb kifejtést igényelne.

\section{Eredmények}

Sokszor a terápiaválasztás alapjául szolgálnak bizonyos „háttérigények”, amelyek leginkább az orvos-beteg kapcsolattal összefüggésben fogalmazódnak meg, így például, hogy az orvossal töltött idő kellő hosszúságú le- gyen, az orvostól kapott figyelem „minőségi” legyen, és hogy a beteg teret kapjon panaszainak közlésére. Fontos háttérigény továbbá az egészségügyi személyzet nonverbális úton is kifejeződő gondoskodása (testi kontaktus, empátia, kedvesség).

Terápiaválasztási tényezőnek minősül és a KAM irányába történő terápiaválasztást idézheti elő, ha a beteg nem kap a nyugati orvoslásban diagnózist vagy nem ért egyet a kapott diagnózissal. Előfordul, hogy a beteg azért választja a KAM-ot, mert nyugati orvosától nem kapott számára kielégítő magyarázatot betegségére, illetve nem ért egyet a nyugati medicina által felkínált magyarázattal. A betegek számos alkalommal nehezményezik a nyugati orvoslásban kapott prognózist vagy azt, ahogyan ezt az orvos közölte. Szintén gyakori, hogy a betegségre nincs nyugati gyógymód, vagy a betegség adott stádiumában nincs elérhető terápia (még nem alakult ki teljesen a betegség vagy végstádiumában van). Gyakran lenne megfelelő nyugati gyógymód, de a beteg nem ért vele egyet, vagy túl kockázatosnak ítéli. Előfordul, hogy a nyugati gyógymód nem hatékony, például krónikus vagy visszatérő megbetegedéseknél. Végül számos esetben a beteg valamely nyugati gyógymód (gyógyszer vagy eljárás) mellékhatásait elviselhetetlennek ítéli, ezért a terápiát megszakítja és az alternatív medicinákban keres gyógymódot, vagy szolgáltatásaikat komplementer terápiaként veszi igénybe a nyugati gyógymód mellékhatásainak enyhítésére.

Eltérő indíttatású terápiaválasztás, amikor a beteg „filozófiai kongruencia” okán dönt a KAM mellett. Ez esetben a beteg magyarázó modelljének (világ-, embervagy betegségképének) egy elemével/elemeivel közös pontot vél felfedezni valamely KAM-terápiában vagy kulturális rendszerben. Ilyenkor a KAM betegségképe vagy etiológiája egyezik a beteg előzetes elképzeléseivel, illetve a KAM-gyógymód egy elfogadható vagy preferált alternatívát nyújt számára, például gyógyszerellenes diszpozícióval rendelkezik és preferálja a „hagyományos” vagy „természetes” kezeléseket. A „holizmus” igénye is képezheti a KAM felé orientálódást, akár úgy, hogy a beteg „a test és lélek” együttes kezeléseként értelmezi, akár úgy, hogy „az egész ember” kezeléseként, azaz nem redukcionista és specializált (külön szakorvos minden panaszra) módon. A KAM világába szintén belépést biztosíthat, ha valaki föként keleti testmozgást (jóga, harcmúvészetek stb.) végez vagy valamely KAM kulturális rendszerén alapuló diétát alkalmaz. Jóllehet, ezek nem közvetlen terápiás jellegúek, később KAM-preferenciákhoz vezethetnek.

Hangsúlyozandó, hogy a fent közölt eredmények nem statikus kategóriákat vagy önálló döntési mechanizmusokat képeznek, hanem különböző, kontextusfüggő okok, amelyekből egy vagy akár több egyidejűleg részét képezheti a KAM irányába történő terápiaválasztási folyamatnak. Alább e háttérigények és terápiaválasztási tényezők pszichoszociális kontextusukban, kulturális beágyazottságukban kerülnek elemzésre. 


\section{Megbeszélés}

\section{Háttérigények}

A betegek számos olyan kielégítetlen igényt fogalmaznak meg, amelyek lényegesek, de önmagában egyik sem indokolja, hogy a KAM világában keressenek gyógyírt betegségükre; ezek mindössze a terápiaválasztási tényezők alapjául szolgáló igények. Az orvos-beteg kapcsolattal összefüggésben három főbb igény merült fel az eddigi terepmunkában: az orvossal töltött idő hossza, az orvostól kapott figyelem „minősége” és a beteg közlési igénye arra vonatkozóan, hogy elmondhassa a számára összefüggő panaszokat.

A közlés igénye (és az orvos erre adott empatikus reflexiója) azért kulcsfontosságú, mert, ahogyan ez minden orvos tapasztalatában megjelenik, a beteg legtöbbször előzetesen kialakított koncepciókkal megy el az orvosi konzultációra, pontosan azért, mert saját információszürő mechanizmusain keresztül már kialakított feltételezéseket állapotára vonatkozóan. Tehát, egyfelől közölni szeretné saját értelmezését és a betegséggel összefüggésbe hozott fizikai és akár pszichoszociális panaszait, másfelól olyan kommunikációra vágyik az orvos részéról, amit ő maga is megért. A megértés igénye nem csak szemantikai értelemben áll fenn, hanem szemiotikai értelemben is. A betegek többsége szomatikus problémáját szociális és pszichológiai kontextusban is szeretné értelmezni [16], amelyre, például, az affektív tartományra is kiterjedő $\mathrm{HKO}$ (legalábbis a vizsgálatban részt vevő betegek tapasztalatai szerint), úgy túnik, jelenleg nagyobb gyakorlati lehetőséget ad, mint az elvileg szintén biopszichoszociális modellben múködő nyugati medicina.

Háttérigény továbbá az orvos és az egészségügyi személyzet gondoskodásának kifejezése, amely leginkább a testi kontaktusban és gesztusokban jelenik meg. A HKO esetében a legfőbb diagnosztikai módszer, a pulzusdiagnosztika, eleve a testi kontaktus mozzanata, de a kezelés során is számos ilyen jelenség adódik. Az akupunktúrás tûk behelyezését is gyakran tapintás előzi meg két fóbb okból: az egyik, hogy a túk helye sokszor egy bizonyos távolságra (cun) van egy anatómiai ponttól, amelyet az orvos a páciens testén, az ujjával mér le. A másik ok, ami miatt létrejön a testi kontaktus, amikor az akupunktőr a tű helyét meghatározó „érzékenységet” keresi. A betegek a testi kontaktus mellett a személyzet mosolygását és kedvességét is sokszor megjegyzik, amelyet a gondoskodás jeleként értelmeznek.

\section{Terápiaválasztási tényezók}

A terepmunka során megismert esetek mindegyikében a beteg nyugati orvoslásban készült leletekkel jött, tehát elsőként a nyugati medicinához fordult, még ha sokszor „csak” a diagnózis/állapotfelmerés érdekében is. Ez egyértelmúen jelzi a nyugati orvoslás domináns presztízsét és az előzetes szocializációs folyamatok során kiala- kult diszpozíciót. Az, hogy milyen döntési mechanizmusok következnek, már komplex kérdés, amelynek tényezői a geertzi Káosz és Kozmosz koncepcióinak segítségével kerülnek ismertetésre.

\section{A Káosz megszüntetésének igénye}

Geertz szerint: „Legalább három olyan pont létezik, ahol a káosz - olyan események halmaza, amelyek nem pusztán értelmezésre várnak, hanem értelmezhetetlenek - fenyegeti az embert: elemzőképessége, türőképessége és erkölcsi belátása határán" [17]. A Káosz megbénítja a mentális és fizikai cselekvőképességet: valami megmagyarázhatatlan és a tehetetlenségérzet hatalmasodik el a személy felett. Geertz úgy véli, hogy az ember nem tud megküzdeni a Káosszal, és Eliade-ra [18] építve, úgy gondolja, az individuum szándéka mindig Kozmoszt, rendet, alakítani az értelmezhetetlenségből. Az összegyüjtött terápiaválasztással kapcsolatos tényezők a geertzi elmélet szerint kategorizálhatók, alapfeltevésként támasztva, hogy az ember mindig igyekszik minél hamarabb Kozmoszt alakítani önmaga számára.

Az elemzóképesség Káosza elsődlegesen a szomatikus panasz értelmezésének kulturális diszpozíciójából származik. Vagyis a páciensnek igénye van arra, hogy panasza számára értelmezhető nevet kapjon, és ezáltal gyógyítható betegséggé konstruálódjon. Diagnózisra szükség van, mint arra is, hogy a beteg betegségének megnevezésével egyetértsen [19]. Nagyon sok beteg, számos lelettel ugyan, de diagnózis nélkül érkezik a HKO-rendelőbe; más betegek a nyugati orvoslás diagnózisával érkeznek, de eltérő etiológiát tulajdonítanak betegségüknek, ezért nem is veszik figyelembe a diagnózist.

Számos olyan eset is van, hogy a beteg megkapta a diagnózist, de kommunikációs problémák miatt számára zűrzavaros vagy elégtelennek vélt magyarázattal távozott orvosától. Példa egy fiatal nő esete, akinél petefészekcisztát diagnosztizáltak és elmondása szerint a (nyugati medicinát képviselő) orvosának indoklása „pusztán” az volt, hogy „hormonok miatt van”. Ez számára nem volt értelmezhető etiológia és a Káosz állapotában maradt.

Szintén az elemzőképesség Káoszának tulajdonítható, ha az elsődleges presztízzsel bíró nyugati orvoslás nem tud gyógymódot kínálni a betegnek. A terápiaválasztás e tényezőjének jelenségei két csoportra bonthatók: 1. a nyugati medicina az adott betegségre nem tud terápiát nyújtani, és 2 . a betegség jelen stádiumában nincs a beteg számára elérhető nyugati gyógymód. A második csoport jelenségei gyakoriak, miszerint a beteg elment nyugati orvosához, esetleg több szakorvoshoz, mint például egy középkorú férfi vérképző szervi megbetegedéssel. A férfival közölték, hogy több mint valószínú, hogy leukémia alakul majd ki nála, „De addig annyit tebetünk, hogy várunk!”. A férfi a „tehetetlenség” érzetével írta le azt a helyzetet, ezért döntött úgy, hogy felkeresi a HKOrendelőt és „tesz valamit a gyógyulásért”. Másik példa: Egy középkorú nő, aki természetgyógyász és a terep- 
munka helyszínén segédkezik, hallásproblémával ment nyugati orvoshoz. Az orvos kérése az volt, hogy ,jöjjön vissza, ha állandósul" a probléma. A nő meglepetten mesélte a történetet, és azt kérdezte: „Vajon azt akarja, addig várjak, amig megsiuketülök?”

A tưrőképesség Káoszát elsődlegesen az idő hiánya okozza, mert gyakran a betegséget csak végstádiumában diagnosztizálják, és így már a konvencionális terápiák sokszor elveszthetik hatékonyságukat. A „feladás” a beteg számára a „Káoszba merülést” jelentené, ezért a KAMban keres megoldást. A türőképességet egy gyógyszer vagy eljárás mellékhatása is próbára teheti. A komplementer gyógymódok alkalmazásában gyakori, hogy a beteg elsősorban nyugati terápiát választ, de a mellékhatások csökkentésére más medicinában keresi a megoldást. Ám olyan is van, hogy a gyógyszer/eljárás mellékhatásai anynyira erősek, illetve a páciens oly mértékben szenved tőlük, hogy úgy dönt, végképp elhagyja a nyugati gyógymódot és alternatív terápiát választ. Ilyen például annak az idős férfinak az esete, akinek Parkinson-kórjára három gyógyszert írt fel orvosa, amiket el is kezdett szedni, de a mellékhatások elviselhetetlenek voltak, ezért (konzultáció nélkül) elhagyta gyógyszereit, és az alternatív medicina számos termékében, szolgáltatásában keresi az enyhülést. A türőképesség Káoszát előidézheti az is, ha egy betegség krónikus, a nyugati terápia hatására hosszú időn át nem enyhül, ezért elszenvedői gyakran a KAM-hoz fordulnak (vö.: [4]). Ugyanez a folyamat következhet be, ha egy betegséget sikerül a nyugati orvoslás kezelésével elmulasztani, de ennek ellenére később visszatér.

Az ember „erkölcsi belátása határán” létrejövő Káosz e témában a nyugati medicinába vetett bizalom részleges vagy teljes elvesztésének különböző jelenségeit involválja. Erkölcsi értelemben Káoszt idéz elö, ha egy beteg úgy véli, nem közölték vele egy eljárás kockázatát; egy gyógyszer/eljárás mellékhatását; félrediagnosztizálták; „rossz” gyógyszert írtak fel neki; orvosa nem közölte vele betegségének kezelésére az összes opciót stb. - vagyis, legalábbis a beteg szerint, olyan mozzanatok nem teljesültek az ellátás során, amelyekre jogszabály kötelez vagy személyes erkölcsi elvárása lenne. Jelen kutatásnak nem célja azt vizsgálni, hogy ezekben az esetekben mi történt „valójában”, hiszen döntő az, hogy az események a betegben olyan bizalomvesztést idéztek elö, hogy a terepmunka helyszínéül szolgáló HKO-rendelőben kötött ki. Fontos azonban kiemelni, hogy a történések megítélésében mennyire jelentős szerepet játszik a beteg információforrások között történő orientációja, hiszen a legtöbb bizalomvesztéssel járó példa abból származik, hogy egy másik információforrás „hiteles” és ellentmondó információval szolgál. Természetesen sokszor pusztán a helyzet testi vetülete áll előtérben (például: rosszullétet okozó mellékhatás), azonban az, hogy a beteg miként értelmezi szomatikus élményeit, már erôsen függ azoktól az információktól, amik alapján interpretálja azokat.

A fenti kijelentést két példa illusztrálhatja. Az egyik egy 82 éves hölgy esete, aki májdaganattal jött a rendelő- be. Korábban számtalan kivizsgálás, nyomon követés történt, a beteget kétszer írták ki mútétre, azonban mindkét mútét meghiúsult kórházi technikai problémák miatt. A beteg a helyzetre kialakult diszpozícióját jól jellemzi, hogy elmondása szerint ,sokkos állapotba” került a második meghiúsult mútét után. A HKO-rendelő betegfelvételén elmesélte, hogy elment magánklinikára is, hogy érdeklődjön a lehetőségeiről és a számára előírt TACE-mütétről, ott azonban közölték vele, hogy a mütétet $50 \%$ esélye van túlélni. A nő felháborodva kijelentette, hogy „Az orvosom nem mondta, hogy ez ezzel jár!” Ezek után következett be nála a teljes bizalomvesztés, és fordult a HKO-hoz. Viszont érdemes hangsúlyozni, hogy a nő nem feltétlen az akupunktúrás kezelésról érdeklődött a HKO-orvosnál, hanem más, olyan nyugati kezelésről, amelyet a (HKO) orvos is ajánlana. Az eset jól példázza azt a helyzetet, amikor a beteg nem a nyugati medicinától fordult el bizalomvesztett állapotában, hanem addigi kezelőorvosától. A HKO-orvost azért választotta, mert egy barátnője azzal ajánlotta, hogy „a doktor úr otthon van mindkét medicinában”.

A második példa szintén mutatja, hogy egy bizalomvesztett állapot miért alakulhatott ki, és hogy milyen jelentős szerepe van az információforrások között történő „hitelességen” alapuló orientációnak. Egy 76 éves hölgy mélyvénás trombózis után került a HKO-rendelőbe; a számára elóírt nyugati terápiát végigvitte $(30$, alhasba adott injekció kombinálva aszpirintablettával). Beszámolt arról, hogy „az orvosom nem mondta”, hogy „nem szabad egyszerre szedni" az aszpirint és injekciókat adni magának. Ennek tulajdonította fennmaradó panaszát (először bal bokán, majd jobb bokán jelentkező seb). Arra a kérdésre, hogy „Honnan tudja, hogy nem lett volna szabad?", a hölgy azt válaszolta, hogy a Kiskegyedben olvasta. Elsőre talán idegennek tünhet, hogy valaki egy ilyen magazint hiteles információforrásnak véljen egészségügyi kérdésekben, de a páciens információszürési mechanizmusa ugyanaz, mint bárki másé: aszerint orientáljuk magunkat, amihez hozzáférünk (előzetes diszpozíciók és egyéb tényezők függvényében), valamint a számunkra fontos kérdésekben elnyert bizalom más tartományokra is áttevődik. (Ha igazat mond egy témában, akkor másban is „hiteles”.) Élményei hatására a beteg teljes bizalomvesztést élt át a nyugati orvoslással kapcsolatban: „Én már csak a jóistenben bizok és magukban!”

$\mathrm{Az}$ „erkölcsi belátás határán” jelentkező Káosz utolsóként bemutatott jelenségében olyan bizalomvesztés áll, amely az orvosi kommunikáció, illetve a beteg pszichoszociális elvárásai ütközőpontján található. Ennek példája egy melldaganattal küzdő középkorú nő narratívája. A narratíva kapcsán ismételten megjegyzendő, hogy a kutatás kizárólag a beteg értelmezését tudja bemutatni, nem pedig azt, hogy a párbeszéd hogyan és milyen kontextusban zajlott beteg és orvos között. A hölgy arról számolt be, hogy akkor döntött úgy, hogy otthagyja nyugati orvosát, amikor a prognózis közlésénél azt mondta neki: „Nem fog idén a karácsonyfa alatt ünnepelni.” Ez a meg- 
jegyzés a betegből haragot és bizalmatlanságot váltott ki, nemcsak a prognózis tartalmát, hanem annak közlési módját illetően is, és bár továbbra is komplementer (nyugati terápia mellett alkalmazott) gyógymódként vette igénybe a HKO-t, orvosával megszakította a kapcsolatot.

Az elemzőképesség, türőképesség és erkölcsi belátás határán jelentkező Káoszra egyaránt gyógyírt biztosíthat egy új Kozmosz kialakítása, amelyet egy új szociokulturális rendszer és az abban fellelhető terápia tehet lehetővé. A KAM által nyújtott, a nyugatitól eltérő betegségkép nemcsak szemiotikai értelemben alakítja át a beteg betegségét (azaz más jelentéssel ruházza fel), hanem fenomenológiai értelemben is, vagyis a beteg szomatikus panaszát másként éli meg a beteg [20]. Így az elemzőképesség Kozmosza az új betegségértelmezésben (amely akár a világképre és emberképre is kiterjedhet) valósul meg, a tûrőképesség Kozmosza a szomatikus érzet megváltozásában, és az erkölcsi értelemben vett Kozmosz pedig az új szociokulturális környezetben jön létre.

\section{A Kozmosz megtartásának igénye}

A KAM erőteljesen kapcsolódik a holizmus, a test-lélekelme egysége, a wellness, az energiaképzetek és a kooperatív gyógyítás értékeihez [1]. Stratton véleménye, hogy az egyén minél inkább magáénak érzi ezeket az értékeket, annál valószínúbb, hogy a KAM-hoz fog fordulni. Astin „filozófiai kongruenciának” nevezi, amikor az individuum és a KAM világnézete egyezik, és azt írja, az amerikai KAM-használók 15-17\%-ának terápiaválasztási indoka „filozófiai okok és preferencia arra, hogy önmaga birkózzon meg problémáival" [1]. Astin a következő értékeket sorolja a filozófiai kongruencia jelenségéhez: a betegséggel kapcsolatos ismeretelméleti elképzelések, a test-elme egységével kapcsolatos kulturális jelentések, az egészség holisztikus megközelítése, a kezelővel fenntartott bensőséges, stabil viszony [1] (vö.: [21], aki természetgyógyász-orvosok pályaválasztásával kapcsolatban vizsgálta a filozófiai kongruenciát).

Számtalan terápiaválasztási tényező magyarázható a filozófiai kongruencia jelenségével, ám az, hogy mennyire egységes „filozófiáról” van szó, már nehezebben meghatározható. A fenti elemekre bontva lehet erról a kulturális „kreolizációról” beszélni, ám személyenként változik, hogy ki milyen elemekkel azonosul. A filozófiai kongruencia miatt bekövetkező terápiaválasztást illetően a nyugati terápiás folyamat megszakítása a leggyakoribb, mégpedig azzal az indokkal, hogy a beteg nem ért egyet a terápiával, eljárással. Ilyen például a rákos megbetegedésekre javasolt kemoterápia és az ízületi gyulladásra ajánlott szteroidos kezelés. Ha egy beteg életveszélyesnek vagy károsnak ítél egy eljárást, sokszor filozófiai kongruencia nélkül is vonzóbb számára a KAM-terápia [7]. Ám ennél jóval gyakoribb, hogy a beteg már prekoncepciókkal bír egy bizonyos gyógymódról, és például egy tumor esetében eldönti, hogy a mütét után nem fogja igénybe venni a kemoterápiát. Ez a diszpozíció visszavezethető a betegségnek tulajdonított etiológiára is, ugyanis, ha valaki arról van meggyőződve, hogy a rák „nem egy betegség, hanem egy gyenge immunrendszer tünete”, akkor számára konzisztens az a feltételezés, hogy nem szabad kemoterápiával kezelni, mert az éppen „a legyengült immunrendszert rombolja", ahogyan ezt az állítást számos, nyugati medicinát képviselő honlapon megtalálhatjuk.

A daganatos megbetegedésekkel kapcsolatban e terápiaválasztási faktornak újabb dimenziója merül fel, miszerint a betegnek nemcsak betegségéről lehetnek előzetes elképzelései, hanem annak diagnosztikájáról is. Ilyenformán elterjedt elképzelés a KAM-ot igénybe vevők körében, hogy egy daganatot nem szabad biopszia útján megvizsgálni, mert ilyenkor az orvos a test által természetes módon kialakított „,édőburkot” (ami elzárja a kóros területet) szúrja ki, megkockáztatva a rákos sejtek elterjedését a szervezet más területeire, tehát a metasztázist.

A filozófiai kongruencia egy újabb eleme a gyógyszerellenes diszpozíció. Sok beteg elsősorban a nyugati ellátórendszert veszi igénybe, de amennyiben orvosa gyógyszeres kezelést ír elő, inkább KAM-ot választ, abban a meggyőződésben, hogy a gyógyszer destruktív hatással van szervezetére és csak legvégső esetben veszi be. Számos KAM-páciens más irányultságú, szélsőségesen gyógyszerellenes diszpozícióval bír: meggyőződésük, hogy a jól jövedelmező gyógyszeripar elsőrangú érdeke, hogy az emberek betegek maradjanak. Gyakran hallani olyan kifejezéseket, mint „gyógyszermaffia” vagy „gyógyszerlobbi”, amely a beteg emberekből él. A betegek mindkét esetben a KAM-terápiát részesítik előnyben.

A gyógyszerellenesség részlegesen magyarázható a „természetességre” való igénnyel, amely a betegek nagy részében felmerül. A „természetes” legtöbbször a „szintetikussal” áll szemben, amely utóbbit a szubjektíven megítélt többségi társadalmi értékekhez lehet kapcsolni, mint az urbanizáció, fogyasztói társadalom, gyors életritmus, alacsony minőségű/káros élelmiszerek, szennyezett környezet stb. Ezért például a sugárkezelés nem minősül „természetesnek”, tehát káros hatással van az emberi szervezetre, de ugyanide sorolhatók a gyógyszerek döntő többsége is. Viszont az akupunktúra esetében például (hiába tekinthető invazív kezelésnek) „a test öngyógyitó mechanizmusát” serkenti és „természetes” beavatkozásnak ítéltetik, ugyanúgy, mint a többi HKO-terápia, fitoterápia stb. Látható, hogy ezek az elképzelések elsősorban általánosabb társadalmi értékekkel társíthatóak, és nem veszik figyelembe a konkrét terápiákkal társuló gyakorlati ismereteket. (Például a „természetesnek” beállított gyógynövények magas és heterogén alkaloidatartalma az olyan „szintetikus”, nagy tisztaságú gyári készítményekkel szemben, amelyek alapja szintén egy természetben is előforduló anyag.)

A legszámottevőbb filozófiai kongruenciaelem a terápiaválasztásban a betegségértelmezést érinti: elterjedt laikus etiológiakoncepció, hogy „minden betegség lelki eredetu"”. Ezen koncepció szerint az egyén gondolatai és érzelmei közvetlen módon hatnak testére és így a meg- 
betegedés és a gyógyulás folyamatában is szervesen részt vesznek. A betegséget magát egy Káosz és kontrollvesztett állapotnak tekinthetjük, amely amennyiben „lelki okokra" vezetik vissza, maximális kontrollt ad a beteg kezébe, hiszen szomatikus panaszának múlása kizárólag tőle (érzelmei, gondolatai megváltoztatásától) függ.

A betegség „lelki evedetu”" okokra való visszavezetése retorikájában és szimbólumkészletében viszonylag könynyen értelmezhető rendszert biztosít a beteg számára, valamint személyre szabható tartalmakká alakítható. A nyugati medicina retorikája egy bizonyos szint után teljesen értelmezhetetlen a laikus számára, valamint a nyugati orvoslás nem rendelkezik a klasszikus értelemben vett szimbolikai rendszerrel. A betegségnek legtöbbször specifikus okot tulajdonít, de ez az ok sokszor jelentés nélküli marad a páciens számára. Amennyiben a beteg betegségét kulturálisan meghatározott szimbolikus tartalmakkal ruházza fel, az nyomban kezelhetőbbé válik (Kozmosz) és nő a beteg kontrollérzete. Éppen ezért fordulhat elő az, hogy egy páciens számára egy adott kulturális közegben egyetlen szó, például: „vese”, többet nyújthat betegsége értelmezésében, mint egy komplex, orvosi magyarázat. Tehát gyakran könnyebben jön létre kongruencia a beteg világ-, ember- és betegségképe, valamint egy adott KAM kulturális rendszere között, hiszen ezekre a medicinákra jellemző, hogy a betegségértelmezés egy egész világképben foglaltatik, amely kiterjed az affektív és interperszonális tartományokra is.

\section{A Kozmosz kiterjesztésének igénye}

A terápiaválasztás más igényeket kielégítő tényezők mentén is létrejöhet, mint például a szakmai vagy laikus kíváncsiság - gyakori indok a „csak érdeklödöm” vagy a „nyitott vagyok bármire, ami az egészséget szolgálja”. Yarney adatai alapján a KAM-használók 31,2\%-a ez utóbbi indokkal vesz igénybe ilyen szolgáltatást; Yarney szerint ez tükrözi a konvencionális kezelés hatékonyságában való kételyt, de ez nem feltétlenül így van. A puszta kíváncsiság is előfordul, amely az akupunktúra esetében a különleges, magyaroknak tán „kultúraidegen” kezelésfajtának is köszönhető, amelyet nem feltétlenül konkrét betegség kapcsán vesznek igénybe, csak például egészségmegőrzési indokkal. Számos olyan nyugati orvos is van, aki szakmai kíváncsiságból és „nyitottságból” vetette alá magát $\mathrm{HKO}$-kezelésnek, hogy jobban tisztában legyen empirikus és elméleti alapjaival.

A KAM világába való „belépés” („entrée”, [22]) fontos módja, hogy az egészséges táplálkozás különböző irányzatain keresztül kiépülhet egy kulturális vonzódás a KAM felé. Megjegyzendő, hogy annak ellenére, hogy a táplálkozás és a mozgás jelentősége ma már a nyugati medicinában is központi jelentőségü, a laikus gondolkodás még mindig könnyebben társítja ezeket a KAM-hoz és sokszor, paradox módon ignorálja a nyugati medicina ezekre vonatkozó ajánlásait. Az étrenddel kapcsolatos jelenségvilág számtalan betegnél összefüggésben van a tár- sadalmi intézményekkel szemben megélt bizalomvesztéssel is, hiszen az élelmiszerek vegyi kezelésével, tartósítószerrel és egyéb, a tömegtermelésben használt vegyi anyagok destruktív hatásával kapcsolatos képzetek állnak mögötte. A KAM világába való entrée másik gyakori útja a (legtöbbször keleti) testmozgás, leginkább a jóga és harcművészetek mögött rejlő tanítások, filozófiák és világképekkel való azonosulás által. Mindemellett fontos még megemlíteni az addikciókezelést is, mint entréet, amely sokszor a KAM világában történik, akár orvosi ajánlásra, amely terápiás tapasztalat később kihathat a páciens más betegségek kapcsán hozott döntéseire is.

Az itt utolsóként tárgyalt tényező, amely a KAM irányába történő terápiaválasztást idézi elő, a magyar identitástudat egyik jelenségköréhez köthető. A magyar kultúra különböző hagyományai, az „osi gyökerek”, az „ősi magyar "vallás és gyógyászat iránti érdeklődés átvezethet más kultúrák hagyományainak kutatásába is, így az alternatív orvoslás témakörébe. E magyarázó modell részeként a betegek a különböző kultúrák hagyományait egyetlen „ösi tudásban” összekapcsolják, amely lehet gyógyászatspecifikus képzetrendszer, de lehetnek olyan kapcsolódási pontok, mint például a gyógyászathoz nem kötődő történelmi vagy vallási elemek.

\section{Következtetések}

A fentebb ismertetett háttérigények az orvos-beteg kapcsolat minőségére, a szubjektív etiológia és tünetösszefüggések iránti közlésvágyra, valamint a testi érintésben megnyilvánuló gondoskodási szándékra terjedtek ki, amelyek erőteljesen befolyásolják a páciens KAM irányába történő orientációját. A tényezők csoportosítása a Káosz-Kozmosz tengely mentén a tehetetlenségérzet különböző megnyilvánulásait mutatta be: az elemzőképesség (nincs diagnózis, nincs gyógymód stb.), a türőképesség (végstádium, mellékhatás stb.) és az erkölcsi dimenzió (bizalomvesztés, a „hiteles” és „jó" orientációs pontjainak megváltozása) tartományában fellépő zürzavart, amelyből a páciens igyekszik kikerülni.

Érdemes hangsúlyozni, hogy a betegeket a napi gyakorlatban a KAM felé fordító számos igény elvileg a nyugati medicinának is központi, hangsúlyos eleme: a beteg közlési igényére és betegségkoncepciójára empatikusan reflektáló aktív figyelem, az érdemi betegtájékoztatás, a közös döntéshozatal a mai nyugati orvoslás központi (sok esetben jogszabályban rögzített) alapkoncepciói közé tartoznak.

A betegben fellépő Káoszból való kiút mindig egy új Kozmosz, egy új rend építése, amelynek építőköveit az alkalmazott KAM mint új kulturális rendszer és pszichoszociális környezet biztosíthatja. A tényezők másik csoportját képezte az az igény, hogy a beteg megtartson egy már meglévő Kozmoszt. Egy olyan személyes életfilozófiai meggyőződést, amely kongruenciát mutat valamely KAM-világképpel és amelynek leggyakoribb képzetelemei a „természetes” gyógymód iránti vonzódás, a gyógy- 
szerellenes diszpozíció és a pszichoszociális faktoroknak tulajdonított etiológia. A tényezők harmadik csoportjában egy már meglévő Kozmosz kiterjesztése iránti igény egyfelől szakmai vagy laikus kíváncsiságot ébreszt a különböző KAM-ok iránt, másfelől entrée-ként szolgálnak olyan tevékenységek (táplálkozás, testmozgás), amelyek valamely KAM kulturális rendszerének részét képezhetik, de nem kapcsolódnak közvetlenül a medicinához.

A tényezők értelmezésében hangsúlyos szerep jut kontextusuknak, hiszen az egyéni döntések mindig a tágabb szociokulturális környezet függvényében születnek meg. Terjedelmi korlátok miatt itt három alapvető globalizációs hatás került rövid ismertetésre. A különféle KAM-ok térnyerése a globális és lokális egészségügyi piac gazdaságpolitikai arénájában zajlik, amelyet financiális és presztízsvezérelt érdekek befolyásolnak, így valamely medicina kulturális termékként való hozzáférhetősége külpolitikai színezettel is bír. Ezen túlmenően az internet és a tömegkommunikációs eszközök uralta információáramlás teszi lehetővé a világ-, ember- és betegségképek terjedését és interakcióját, amely kulturális „kreolizációhoz” vezet. Ezt az interakciót illusztrálja az „osi magyar” identitás fúziója más kultúrák „ősi tudásával” és közös „gyökerek” konstruálásával, amely a medicinában is gyakorta megjelenik. A szinte határtalan információáramlás hátszelét a policentrikus információtermelés biztosítja, amely a társadalmi intézmények tekintélyvesztésével tandemben egyre inkább a szubjektumba helyezi a „hitelesség” és a „jó, helyes” megítélésének orientációs iránytüjét. Egy adott terápia kapcsán szerzett személyes tapasztalat mérvadó a terápia további alkalmazásában és javasolásában, ugyanakkor a szubjektív orientációs iránytü is egyre szomatikusabb jellegú, intuitív - ahogy egy páciens az információforrások hitelességének mérlegelése kapcsán megjegyezte: „A szípemen keresztül szüröm meg."

Anyagi támogatás: A közlemény megírása anyagi támogatásban nem részesült.

Szerzôi munkamegosztás: Z. Sz.: Kulturális antropológiai terepmunka, mélyinterjúk készítése, az adatok rögzítése, a cikk megírása. P. Gy.: Támogatás a kutatás során szerzett ismeretanyag orientációjában és az adatok értelmezésében, a cikk megírásában való részvétel. $\mathrm{Z}$. Á.: Részvétel a cikk megírásában, szakmai segítségnyújtás. A cikk végleges változatát mindhárom szerző elolvasta és jóváhagyta.

Érdekeltségek: A szerzőknek nincsenek érdekeltségeik.

\section{Irodalom}

[1] Stratton, T. D., McGivern-Snofsky, J. L.: Toward a sociological understanding of complementary and alternative medicine use. J. Altern. Complement. Med., 2008, 14(6), 777-783.

[2] Hlubocky, F. J., Ratain, M. J., Wen, M., et al.: Complementary and alternative medicine among advanced cancer patients en- rolled on phase I trials: A study of prognosis, quality of life, and preferences for decision making. J. Clin. Oncol., 2007, 25(5), $548-554$.

[3] Udvardy, M.: Complementary and alternative medicine, relation to clinical haematology. [Komplementer és alternatív gyógyászat és a rosszindulatú vérképzőszervi betegségek.] Magyar Tudomány, 2011, 172(3), 322-330. [Hungarian]

[4] Faith, J., Thorburn, S., Tippens, K. M.: Examining CAM use disclosure using the Behavioral Model of Health Services Use. Complement. Ther. Med., 2013, 21(5), 501-508.

[5] Zuzak, T. J., Boňková, J., Careddu, D., et al.: Use of complementary and alternative medicine by children in Europe: Published data and expert perspectives. Complement. Ther. Med., 2013, 21(Suppl. 1), S34-S47.

[6] Varga, O.: Integration of Complementary and Alternative Medicine into modern medicine with special emphasis on medical education and legal regulation in Hungary. PhD-thesis. [A természetgyógyászat integrációja a modern medicinába, különös tekintettel az orvosképzésre és a hazai jogi szabályozásra. PhDértekezés.] Debreceni Egyetem, Orvos- és Egészségtudományi Centrum, Népegészségügyi Kar, Magatartástudományi Intézet, Debrecen, 2007. [Hungarian]

[7] Yarney, J., Donkor, A., Opoku, S. Ү., et al.: Characteristics of users and implications for the use of complementary and alternative medicine in Ghanaian cancer patients undergoing radiotherapy and chemotherapy: a cross-sectional study. BMC Complement. Altern. Med., 2013, 13(1), 16.

[8] Lövgren, M., Wilde-Larsson, B., Hök, J., et al.: Push or pull? Relationships between lung cancer patients' perceptions of quality of care and use of complementary and alternative medicine. Eur. J. Oncol. Nurs., 2011, 15(4), 311-317.

[9] Hasan, S. S., See, C. K., Choong, C. L., et al.: Reasons, perceived efficacy, and factors associated with complementary and alternative medicine use among Malaysian patients with HIV/AIDS. J. Altern. Complement. Med., 2010, 16(11), 1171-1176.

[10] Van Wolputte, S.: Hang on to your self: of bodies, embodiment, and selves. Ann. Rev. Anthropol., 2004, 33, 251-269.

[11] Varga, O.: Who would you choose? [Mondd, te kit választanál?] LAM, 2007, 17(4-5), 368-370. [Hungarian]

[12] Molnár, A. K.: New religious phenomena. In: Lugosi, Á., Lugosi, G. (eds.): Sects, new religious phenomena. [Új vallási jelenségek. In: Lugosi, Á., Lugosi, G. (szerk.): Szekták, új vallási jelenségek.] Pannonica Kiadó, Budapest, 1998. [Hungarian]

[13] Eriksen, T. H.: Small places, large issues: An introduction to social and cultural anthropology. Pluto Press, London, 2001.

[14] Hajer, M.: Policy without polity? Policy analysis and the institutional void. Policy Sciences, 2003, 36(2), 175-195.

[15] Knoll, A. M.: The reawakening of complementary and alternative medicine at the turn of the twenty-first century: filling the void in conventional biomedicine. J. Contemp. Health Law Policy, 2004, 20(2), 329-366.

[16] Kleinman, A.: Concepts and a model for the comparison of medical systems as cultural systems. Soc. Sci. Med., 1978, 12(2B), 85-95.

[17] Geertz, C.: The interpretation of cultures. Osiris Kiadó, Budapest, 2001

[18] Eliade, M.: The myth of the eternal return. Európa Könyvkiadó, Budapest, 2006

[19] Helman, C. G.: Culture, health and illness. Butterworth-Heinemann, Oxford, 1994.

[20] Csordas, T. J.: The sacred self: A cultural phenomenology of char ismatic healing. University of California Press, California, 1997.

[21] Weeks, J.: CAM consult: What makes a physician an expert in CAM? Med. Econ., 2000, 77(14), 109-110, 117.

[22] Sivén, J., Mishtal, J.: Yoga as entrée to complementary and alternative medicine, and medically pluralistic practices. Human Organiz, 2012, 7l(4), 348-357.

(Zörgő Szilvia,

Budapest, Nagyvárad tér 4., 1089 e-mail: zorgoszilvia@gmail.com) 